\title{
Comparative Analysis of Prickles on Rubus sieboldii (Rosaceae) between Grazed and Ungrazed Areas in Southwestern Shikoku, Japan
}

\author{
Shogo Takei ${ }^{1}$, Kyohei Ohga ${ }^{1}$, Hiroshi Hayakawa ${ }^{2}$, Jun Yokoyama ${ }^{3}$, Katsura Ito $^{2}$, Shin-ichi Tebayashi ${ }^{2}$, Ryo \\ Arakawa $^{2} \&$ Tatsuya Fukuda ${ }^{2}$ \\ ${ }^{1}$ Graduate School of Integrated Arts and Sciences, Kochi University, Monobe 200, Nankoku, Kochi 783-8502, \\ Japan \\ ${ }^{2}$ Faculty of Agriculture, Kochi University, Monobe 200, Nankoku, Kochi 783-8502, Japan \\ ${ }^{3}$ Faculty of Science, Yamagata University, Kojirakawa, Yamagata 990-8560, Japan \\ Correspondence: Tatsuya Fukuda, Faculty of Agriculture, Kochi University, Monobe 200, Nankoku, Kochi \\ 783-8502, Japan. Tel: 81-88-864-5140. E-mail: tfukuda@kochi-u.ac.jp
}

Received: December 7, 2012 Accepted: January 23, 2012 Online Published: January 30, 2013

doi:10.5539/jps.v2n1p152 URL: http://dx.doi.org/10.5539/jps.v2n1p152

\begin{abstract}
Kashima Island $\left(32^{\circ} 57^{\prime} \mathrm{N}, 132^{\circ} 27^{\prime} \mathrm{E}\right)$ is a very small island ( $\left.45.1 \mathrm{ha}\right)$ in southwestern Shikoku, Japan with a high density (ca. 38.5/ $\mathrm{km}^{2}$ ) of Sika deer (Cervus nippon). To examine induced defences of plants against the Sika deer, we conducted morphological analyses of prickles of Rubus sieboldii Blume (Rosaceae) between grazed (Kashima Island) and ungrazed areas (neighbour locations) in southwestern Shikoku. The length and density of prickles on leaves and around stems were measured. The prickles of the plants on Kashima Island were significantly longer and denser than those of the other areas, implying that the increased length and density of prickles were an induced defence of $R$. sieboldii on Kashima Island.
\end{abstract}

Keywords: island, sika deer, herbivory, density, blackberry, prickle length, defence

\section{Introduction}

Plant-herbivore interactions are widespread in ecosystems, and the plants have evolved a variety of defences against herbivory, such as chemical substances and structural modifications (Janzen, 1966; Bernays \& Janzen, 1988; Yamazaki \& Kikuzawa, 2003). The structural modifications of plants such as thorns, spines, and prickles are often assumed as anti-herbivore defences, especially against large herbivores. Therefore, unpalatable plants could be selected for to avoid grazing and browsing under a high density of herbivores (Janzen 1986; Bernays \& Janzen, 1988; Brazely et al., 1991; Matsuki et al., 2004). In Japan, some plants had gained characteristic morphologies to avoid grazing from Sika deer (Cervus nippon) on a small island. For example, Kinkazan Island is a small land mass situated about one $\mathrm{km}$ off the Pacific coast of Honshu, with a high density of Sika deer (ca. $63.2 / \mathrm{km}^{2}$ ) that have been protected for a long time as sanctuary animals (Takatsuki, 1983). Cirsium amplexifolium (Nakai) Kitam. var. muraii (Kitam.) Kitam. (Asteraceae) is endemic to this island and has longer spines around the leaf edges and stems than those in Cirsium amplexifolium var. amplexifolium, which occurs in wide areas in northern Honshu (Kitamura, 1981). Takatsuki (2006) suggested that, in Cirsium amplexifolium var. muraii, the long spines might have been selected to avoid heavy grazing by the Sika deer.

Kashima Island $\left(32^{\circ} 57^{\prime} \mathrm{N}, 132^{\circ} 27^{\prime} \mathrm{E}\right)$ is a very small land area (45.1 ha) in southwestern Shikoku, Japan (Figure 1). The climate of this island lies in the warm temperate zone; the mean temperature of the coldest month (January) is $7.1^{\circ} \mathrm{C}$ and the annual precipitation is $1903 \mathrm{~mm}$ (data taken at Misho in Ainan-cho) according to the Japan Meteorological Agency (2011). Evergreen broad-leaved forests are the climax vegetation (Hashigoe, 1995). Some unpalatable plants have become prominent on the island because of the high density (ca. $\left.38.5 / \mathrm{km}^{2}\right)$ and heavy grazing of Sika deer (Figure 2A) (Takatsuki, 1982a, b; Hashigoe, 1995). Takatsuki (1982a) performed a cafeteria test, offering 63 species of plants to Sika deer, 36 of which the deer avoided eating. One of these, Rubus sieboldii Blume, which is distributed from the western Honshu to Ryukyu archipelago (Momiyama, 1989), was probably not consumed because of its prickles which served as anti-herbivore defence (Figure 2B) (Takatsuki, 1982a). If its prickles are defensive structures, it is possible that they could be induced; one may expect long and densely distributed defence structures on plant parts that have been subjected to herbivory. Therefore, it is 
possible that the prickles on plants in this island are longer than that on plants of the same species from other areas. The aim of this study was to examine the prickle legethening of this species by comparing individuals on Kashima Island with those of the neighbouring areas.

\section{Materials and Methods}

The samples of 118 individuals of Rubus sieboldii used in this study were collected in 2011 from Kashima Island and the four neighbouring areas (Figure 1, Table 1).

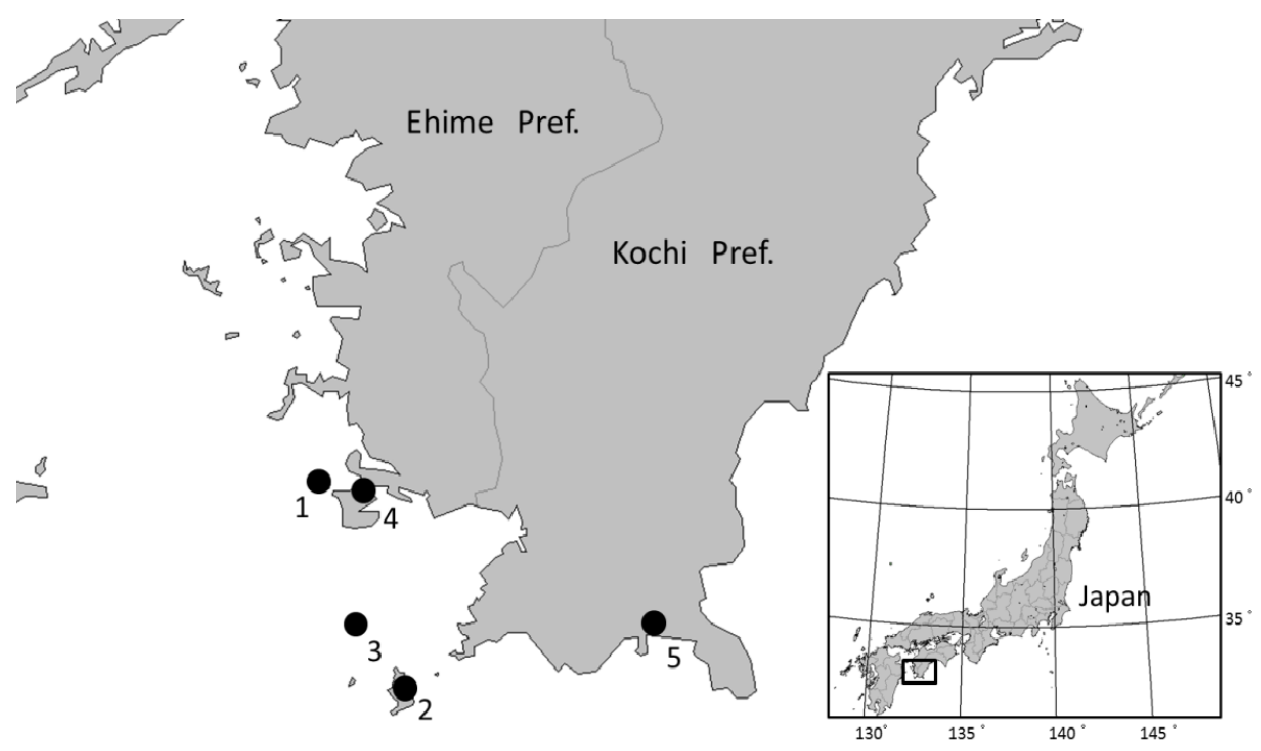

Figure 1. Sampling locations used in this study

1 - Kashima Island, 2- Okinoshima Island, 3- Uguru Island, 4- Uchidomari, and 5- Matsuzaki.

Table 1. Sampling locations in this study

\begin{tabular}{|c|c|c|c|c|}
\hline $\begin{array}{l}\text { Location } \\
\text { name }\end{array}$ & $\begin{array}{l}\text { Location } \\
\text { no. }\end{array}$ & $\begin{array}{l}\text { Number of } \\
\text { Individuals }\end{array}$ & Location & $\begin{array}{l}\text { Latitude and } \\
\text { longitude }\end{array}$ \\
\hline $\begin{array}{l}\text { Kashima } \\
\text { Island }\end{array}$ & 1 & 35 & $\begin{array}{c}\text { Ehime Prefecture, Minamiuwa-Gun, } \\
\text { Ainan-Cho, } \\
\text { Kashima Island }\end{array}$ & $\begin{array}{l}\text { N } 32^{\circ} 56^{\prime} \\
\text { E } 132^{\circ} 27^{\prime}\end{array}$ \\
\hline $\begin{array}{l}\text { Okinoshima } \\
\text { Island }\end{array}$ & 2 & 12 & $\begin{array}{c}\text { Kochi Prefecture, Sukumo City, } \\
\text { Okinoshima-Cho, } \\
\text { Okinoshima Island }\end{array}$ & $\begin{array}{l}\text { N } 32^{\circ} 43^{\prime} \\
\text { E } 132^{\circ} 32^{\prime}\end{array}$ \\
\hline Uguru Island & 3 & 23 & $\begin{array}{c}\text { Kochi Prefecture, Sukumo City, } \\
\text { Okinoshima-Cho, } \\
\text { Uguru Island }\end{array}$ & $\begin{array}{l}\text { N } 32^{\circ} 48^{\prime} \\
\text { E } 132^{\circ} 29^{\prime}\end{array}$ \\
\hline Uchidomari & 4 & 20 & $\begin{array}{l}\text { Ehime Prefecture, Minamiuwa-Gun, } \\
\text { Ainan-Cho, } \\
\text { Uchidomari }\end{array}$ & $\begin{array}{l}\text { N } 32^{\circ} 56^{\prime} \\
\text { E } 132^{\circ} 30^{\prime}\end{array}$ \\
\hline Matsuzaki & 5 & 28 & $\begin{array}{c}\text { Kochi Prefecture, Tosashimizu City, Kagumi } \\
\text { Matsuzaki }\end{array}$ & $\begin{array}{l}\text { N } 32^{\circ} 46^{\prime} \\
\text { E } 132^{\circ} 55^{\prime}\end{array}$ \\
\hline
\end{tabular}



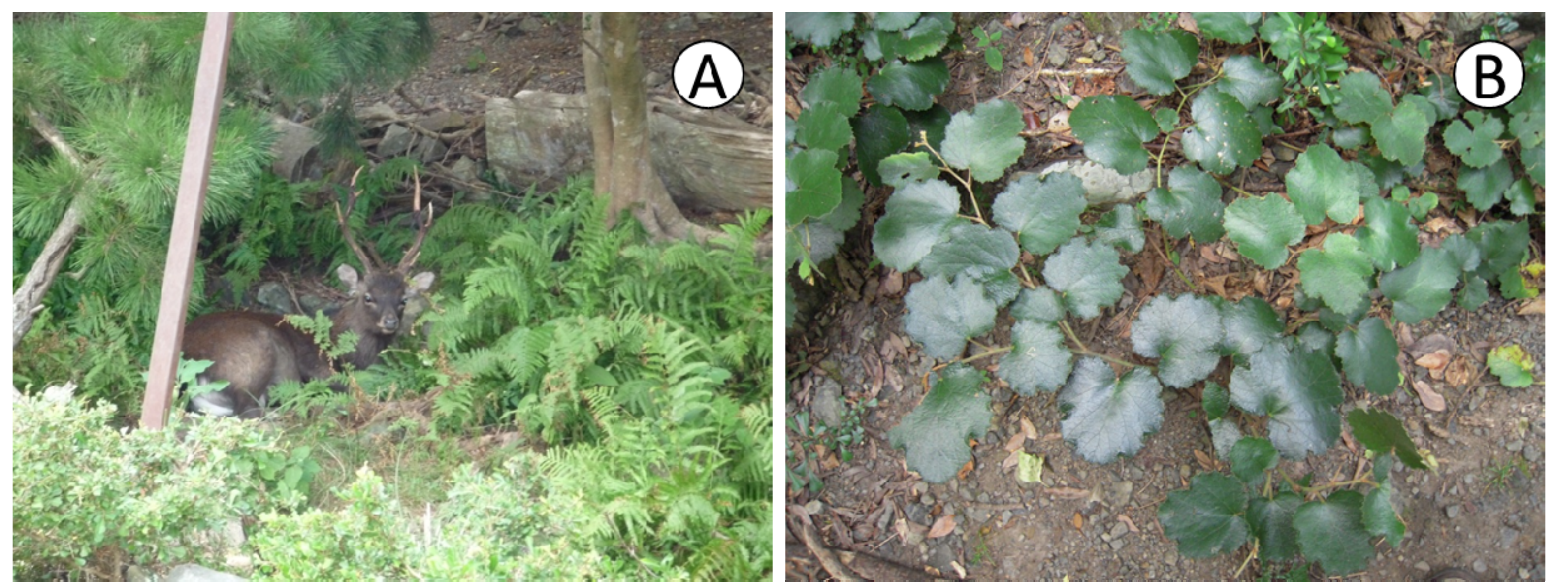

Figure 2. Sika deer (A) and Rubus sieboldii (B) in Kashima Island

To measure the length and density of prickles on the adaxial and abaxial sides of the leaves and prickles around stems of $R$. sieboldii, five fully expanded leaves at the middle part of the shoot of each plant were collected per individual. The average length of leaf prickle on a plant was calculated by measuring 10 prickles per leaf under a microscope, on five leaves per plant. The density of prickles was calculated by averaging the number on a square section from those five leaves per individual. The average length of prickles on a stem was calculated as the average from five prickles at 10 locations near the middle part of the height of the stem. The density was measured by counting the number per a square section of surface area around the stem at 10 locations on each individual. All study-specific statistical analyses were performed using SPSS Statistics 19 (IBM SPSS, Chicago, Illinois).

\section{Results and Discussion}

We analyzed the length and density of prickles on the adaxial and abaxial sides of leaves and around stems of Rubus sieboldii on opposite shores of Kashima Island and neighbouring islands (Okinoshima and Uguru Islands) (Figure 1). The results of morphological analysis are shown in Table 2 and Figure 3. R. sieboldii on Kashima Island had significantly longer and denser prickles on the stem than plants from the other areas (Table 2), suggesting that the high density and grazing pressure of Sika deer were correlated with the increased length and density of prickles of $R$. sieboldii in Kashima Island. Our results were similar to those mentioned above for Cirsium amplexifolium var. muraii in Kinkazan Island, Japan, another location with a high density of Sika deer (Takatsuki, 1977; 2006). However, it is questionable whether such ecological response would arise under exposure to a high density of herbivores. Some studies have reported that a high density of herbivores has been correlated with longer thorns. For example, Pullin and Gibert (1989) indicated that grazing pressure on Urtica dioica L. (Urticaceae) led to high stinging trichome densities after grazing and mechanical damage between the grazed and ungrazed areas. Moreover, branches of Acacia drepanolobium Harms ex Sjöstedt (Fabaceae) within reach of goats had significantly longer thorns than higher branches on the same plants or branches at all heights on nearby plants protected from ungulate herbivory (Young, 1987), and a similar pattern has been reported qualitatively on trees eaten by giraffes (Foster \& Dagg, 1972). In addition, Milewski et al. (1991) and Takada et al. (2003) reported that the degree of herbivory was different between prickled and non-prickled Acacia seyal Del. and Damnacanthus indicus C. F. Gaertn., respectively. Studies on various other species have shown that actual and simulated herbivory correlated with long thorns (Abrahamson, 1979; Myers, 1987; White, 1988). In addition, most of these studies showed that the morphological modifications of plants occurred after a short period under high herbivore density. Takatsuki (2006) also claimed that such modifications on plants on Kinkazan Island in Japan appeared quickly under exposure to a high density of Sika deer. From these results, therefore, we expected that the high grazing pressure in Kashima Island should quickly lead to the increased length and density of prickles on both sides of leaves and shoots of $R$. sieboldii, implying that it is due to induced defence of $R$. sieboldii to sika deer herbivory. 
Table 2. Morphological measurements (average \pm standard deviation) of Rubus sieboldii

\begin{tabular}{|c|c|c|c|c|c|}
\hline Location & Kashima Island & Okinoshima Island & Uguru Island & Uchidomari & Matsuzaki \\
\hline \multicolumn{6}{|l|}{ Leaf prickles } \\
\hline \multicolumn{6}{|l|}{ adaxial side } \\
\hline length (mm) & $1.71 \pm 0.55 \mathrm{a}$ & $1.29 \pm 0.51 \mathrm{ab}$ & $1.19 \pm 0.23 b$ & $1.01 \pm 0.40 \mathrm{~b}$ & $1.15 \pm 0.25 \mathrm{ab}$ \\
\hline density $\left(\mathrm{N} / \mathrm{cm}^{2}\right)$ & $0.50 \pm 0.47 \mathrm{a}$ & $0.15 \pm 0.19 \mathrm{ab}$ & $0.46 \pm 0.32 \mathrm{ab}$ & $0.04 \pm 0.06 \mathrm{~b}$ & $0.45 \pm 0.41 \mathrm{ab}$ \\
\hline \multicolumn{6}{|l|}{ abaxial side } \\
\hline length (mm) & $1.22 \pm 0.30 \mathrm{a}$ & $0.86 \pm 0.33 b$ & $0.84 \pm 0.16 \mathrm{~b}$ & $0.84 \pm 0.21 \mathrm{~b}$ & $0.87 \pm 0.12 b$ \\
\hline density $\left(\mathrm{N} / \mathrm{cm}^{2}\right)$ & $0.72 \pm 0.43 \mathrm{a}$ & $0.23 \pm 0.30 \mathrm{bc}$ & $0.46 \pm 0.28 \mathrm{abc}$ & $0.16 \pm 0.16 \mathrm{c}$ & $0.65 \pm 0.42 \mathrm{ab}$ \\
\hline \multicolumn{6}{|l|}{ Stem prickles } \\
\hline length (mm) & $1.57 \pm 0.42 \mathrm{a}$ & $1.03 \pm 0.30 \mathrm{~b}$ & $1.08 \pm 0.13 b$ & $1.16 \pm 0.24 b$ & $1.16 \pm 0.22 b$ \\
\hline density $\left(\mathrm{N} / \mathrm{cm}^{2}\right)$ & $11.25 \pm 4.61 \mathrm{a}$ & $5.53 \pm 2.61 b$ & $6.81 \pm 2.23 b$ & $5.03 \pm 2.88 \mathrm{~b}$ & $7.92 \pm 2.29 \mathrm{~b}$ \\
\hline
\end{tabular}

Columns marked by different letters differ significantly according to the Scheffe test $(p<0.05)$.
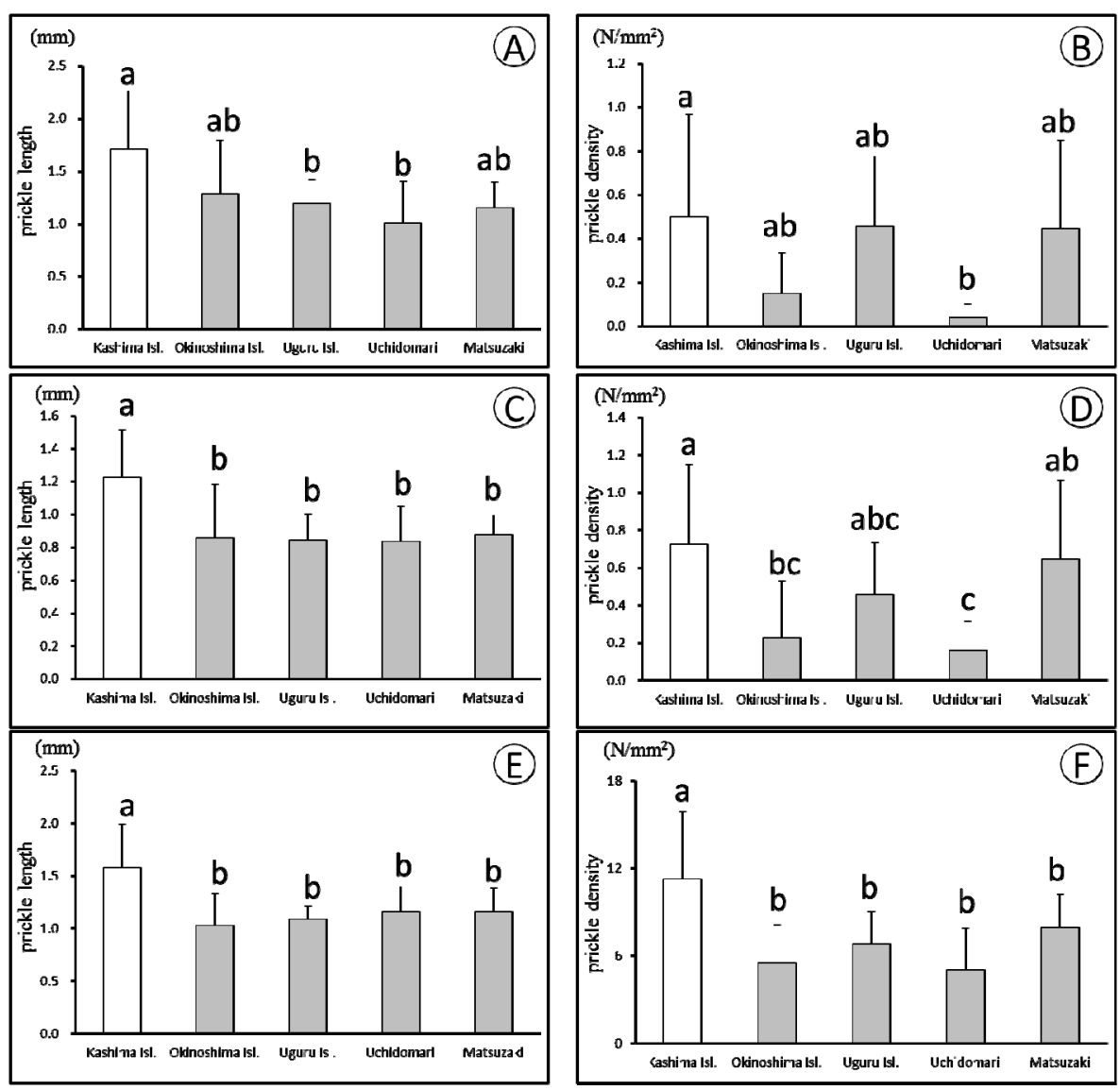

Figure 3. Morphological measurements of prickles of Rubus sieboldii. (A) length on adaxial side of leaf; (B) density on adaxial side of leaf; (C) length on the abaxial side of leaf; (D) density on the abaxial side of leaf; (E, F) length and density around the stem

\section{Acknowledgements}

We thank Mr. Moriguchi Y. for providing useful comments on Kashima Island and Drs. Minamiya Y., Tsuchiya Y., Yoshimi Y., Muroi M., Miyata H., Isomoto S., Matsuyama K., Yokoyama N., Kumekawa Y., Kakimoto N., Sunami T., and Matsui R. for providing us with much-needed assistance. This study was partly supported by a Grant-in-Aid for Scientific Research from the Ministry of Education, Science and Culture of Japan (to TF and 
JY).

\section{References}

Abrahamson, W. G. (1975). Reproductive strategies of dewberries. Ecology, 56(3), 721-726. http://dx.doi.org/10.2307/1935508

Bernays, E. A., \& Janzen, D. H. (1988). Saturniid and Sphingid caterpillars-2 ways to eat leaves. Ecology, 69(4), 1153-1160. http://dx.doi.org/10.2307/1941269

Bazely, D. R., Myers, J. H., \& da Silva, K. B. (1991). The response of numbers of bramble prickles to herbivory and depressed resource availability. Oikos, 61(3), 327-336. http://dx.doi.org/10.2307/3545240

Foster, J. B., \& Dagg, A. I. (1972). Notes on the biology of the giraffe. African Journal of Ecology, 10(1), 1-16. http://dx.doi.org/10.1111/j.1365-2028.1972.tb00855.x

Hashigoe, S. (1995). Flora of Kashima Island, Ehime Prefecture, Japan. Biology in southern Ehime, 8, 22-32 (in Japanese).

Janzen, D. H. (1966). Coevolution of mutualism between ants and acacias in Central America. Evolution, 20(3), 249-275. http://dx.doi.org/10.2307/2406628

Janzen, D. H. (1986). Chihuahuan desert nopaleras: defaunated big mammal vegetation. Annual Review of Ecology and Systematics, 17, 595-636. http://dx.doi.org/10.1146/annurev.es.17.110186.003115

Japan Meteorological Agency. (2011). Average of rainfall and temperature from 1981 to 2010 at Misho, Ainan-cho, Ehime prefecture, Japan. Retrieved from http://www.jma.go.jp/jma/indexe.html

Kitamura, S. (1981). Compositae (Asteraceae). In Y. Satake, J. Ohwi, S. Kitamura, S. Watari \& T. Tominari (Eds.), Wild Flowers of Japan Herbaceous Plants Vol. III. (pp. 156-235). Tokyo: Heibonsha Ltd (in Japanese).

Matsuki, S., Sano, Y., \& Koike, T. (2004). Chemical and physical defense in early and late leaves in three heterophyllous birch species native to northern Japan. Annals of Botany, 93(2), 141-147. http://dx.doi.org/10.1093/aob/mch022

Mayers, J. H. (1987). Nutrient availability and the deployment of mechanical defenses in grazed plants: a new experimental approach to the optimal defense theory. Oikos, 49(3), 350-351. http://dx.doi.org/10.2307/3565772

Milewski, A. V., Young, T. P., \& Madden, D. (1991). Thorns as induced defences: experimental evidence. Oecologia, 86(1), 70-75. http://dx.doi.org/10.1007/BF00317391

Momiyama, Y. (1989). Rubus L. In Y. Satake, H. Hara, S. Watari \& T. Tominari (Eds.), Wild Flowers of Japan Woody Plants Vol. I. (pp. 204-215). Tokyo: Heibonsha Ltd (in Japanese).

Pullin, A. S., \& Gilbert, J. E. (1989). The stinging nettle, Urtica dioica, increases trichome density after herbivore and mechanical damage. Oikos, 54(3), 275-280. http://dx.doi.org/10.2307/3565285

Takada, M., Asada, M., \& Miyashita, T. (2003). Can spines deter deer browsing? a field experiment using a shrub Damnacanthus indicus. Journal of Forest Research, 8(4), 321-323. http://dx.doi.org/10.1007/s10310-003-0043-1

Takatsuki, S. (1977). Ecological studies on effect of Sika deer (Cervus nippon) on vegetation I: evaluation of grazing intensity of Sika deer on the vegetation in Kinkazan Island, Japan. Ecological Review, 18(4), 233-250.

Takatsuki, S. (1982a). Ecological studies on effect of Sika deer (Cervus nippon) on vegetation III: the vegetation of Iyo-Kashima Island, southwestern Shikoku, with reference to grazing effect of Sika deer. Ecological Review, 20(1), 15-29.

Takatsuki, S. (1982b). A note on the herd size of Sika deer on Kashima Island. Journal of Mammalogical Society of Japan, 9, 54-56.

Takatsuki, S. (1983) .Group size of Sika deer in relation to habitat type on Kinkazan Island. Japanese Journal of Ecology, 33, 419-425.

Takatsuki, S. (2006). Ecological history of Sika deer. University of Tokyo Press, Tokyo (in Japanese).

White, P. S. (1988). Prickle distribution in Aralia spinosa (Araliaceae). American Journal of Botany, 75(2), 282-285. http://dx.doi.org/10.2307/2443895 
Yamazaki, M., \& Kikuzawa, K. (2003). Temporal and spatial variations in leaf herbivory within a canopy of Fagus crenata. Oecologia, 137(2), 226-232. http://dx.doi.org/10.1007/s00442-003-1337-x

Young, T. P. (1987). Herbivory induces increased thorn length in Acacia drepanolobium. Oecologia, 71, 436-438. http://dx.doi.org/10.1007/BF00378718 